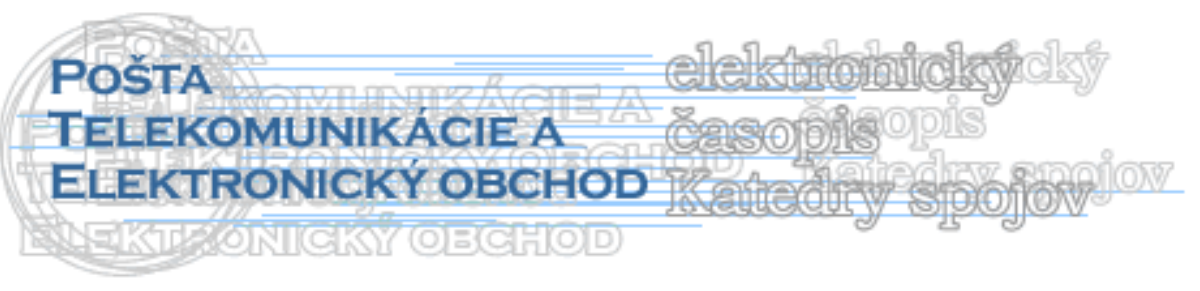

\title{
INOVÁCIE A ZNALOSTNÝ MANAŽMENT
}

\author{
Milan Kubiček - Katarína Hrbáňová
}

\section{Úvod}

Inovácia znamená obnovu a zmenu, ale v dnešnom svete obchodu znamená najmä rozvoj nových podnikových služieb, výrobkov, procesov a štruktúr. Rozvoj a uplatňovanie nových poznatkov predstavuje základ inovácie, s dôrazom na silné väzby medzi inováciami a znalost'ami.

Zlúčenie výrobných faktorov (v tomto prípade vrátane znalostí), vedie k rozvoju kl'účových kompetencií, klúčových produktov a nakoniec i finálnych výrobkov. Inými slovami, výnosy sú generované z akýchkol'vek vytvorených znalostí.

Môže to byt' dlhý proces a môže to trvat' aj niekol'ko rokov od rozvoja znalosti až po prijatie odpovede z ciel'ového trhu pre dané tovary a služby. Organizovanie tohto procesu je jednou z odborných úloh inovačného manažmentu. Efektívny inovačný manažment riadi proces od vývoja znalosti až po konečnú realizáciu a využitie výsledkov.

Inovačný manažment je riadenie aktivít tvorby nového alebo inovovaného objektu, (výrobok, proces, služba) v rámci všetkých etáp reprodukčného procesu (predvýrobná etapa, výrobná etapa, odbytová etapa). Hlavnou úlohou inovačného manažmentu je previest' nové myšlienky (výsledky vedy a výskumu) $\mathrm{z}$ ich teoretickej podoby ku konkrétnej aplikácii (k spotrebitel’ovi). Inovácia je tu definovaná ako prakticky zrealizovaná myšlienka (uvedenie nového výrobku na trh, nábeh nového procesu apod.), znamená prechod do nového, lepšieho stavu (reprezentovaný inovačnými stupňami). Základom inovácie je invencia, čo je nová myšlienka o možnej zmene, o novom technickom riešení. [4]

Trh, pôsobí ako externý hodnotitel' v oblasti inovácií a znalostného manažmentu. Vnútorné hodnotenie môže byt' vykonané prostredníctvom vizualizácie vývoja organizačných základných kompetencií a kultúry vo, forme stromu základných kompetencií. V ideálnom prípade by mal byt' strom základných kompetencií konštruovaný tak, aby mohli byt' rovnaké znalosti použité na realizáciu l’ubovol'ného počtu rôznych zákazníckych riešení.

Individuálne požiadavky zákazníkov môžu byt' brané do úvahy prostredníctvom prispôsobenia a diverzifikácie na úrovni konečného výrobku. To môže byt' dosiahnuté len zameraním sa na štandardný rozsah základných produktov. Mnoho spoločností zanedbáva tento faktor, a namiesto toho sú nútení investovat' do nového vývoja aby naplnili požiadavky zákazníkov.

\footnotetext{
- Ing. Milan Kubiček, Katedra spojov, Fakulta prevádzky ekonomiky dopravy a spojov, Žilinská univerzita v Žiline, Univerzitná 1, 01026 Žilina, tel.: +421 41513 3145, e-mail: Milan.Kubicek@fpedas.uniza.sk

- Ing. Katarína Hrbáňová, Katedra spojov, Fakulta prevádzky ekonomiky dopravy a spojov, Žilinská univerzita v Žiline, Univerzitná 1, 01026 Žilina, tel.: +421 41513 3145, e-mail: Katarina.Hrbanova@fpedas.uniza.sk
} 


\section{Podpora inovácie znalostným manažmentom}

Podnety pre inovačné projekty môžu pochádzat' z dvoch rôznych zdrojov: neplánovaná inovácia sa objaví počas bežných obchodných činností a je často výsledkom nového zákazníckeho projektu. Plánovaná inovácia na druhej strane aktívne využíva dostupné znalostné zdroje a to ako v spoločnosti, tak aj pri vývoji nových procesov vytvárania hodnoty.

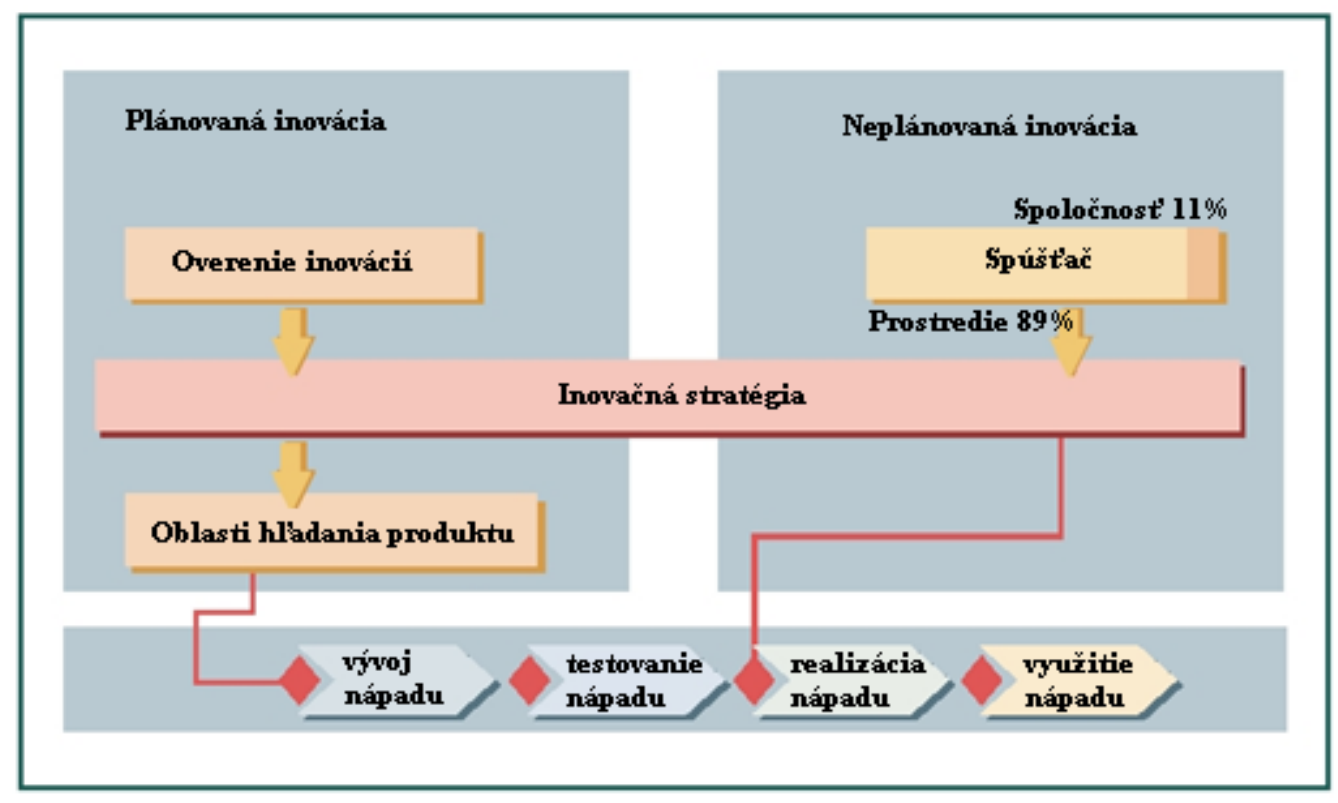

Obrázok 1: Rôzne inovačné aktivity v spoločnosti [2]

Pravidelné kontroly inovácie slúžia na analýzu stavu stromu základných kompetencií organizácie, ako aj príslušných trendov a vývojov v prostredí. Výsledky môžu byt' následne použité na vytvorenie alebo zmenu inovačnej stratégie a definovanie rozsahu a ciel'ov inovačných projektov.

V praxi sa ukázalo ako efektívne rozdelenie inovačného procesu/projektu, do nasledujúcich fáz:
o vývoj nápadu
o testovanie nápadu
o realizácia nápadu
o využitie nápadu

Vývojová fáza sa zameriava na uplatňovanie tvorivých metód (napr. brainstorming) na identifikáciu a uvol'nenie tvorivého potenciálu. Najsl'ubnejšie nápady (úspešnost' cca. 12\%) sú potom odfiltrované do testovacej fázy. Nápady by teraz mali byt' detailne preskúmané, aby sa zabezpečilo, že nie sú zahrnuté v existujúcich právach duševného vlastníctva. Nové znalosti sa môžu dat' strategicky chránit’ patentom.

Perspektívne nápady, ktoré prešli fázou testovania sú potom rozvinuté v následnej fáze realizácie. Projektový manažment, znalostná logistika, aktivity plánovania a inovačného marketingu sú klúčovými prvkami v tejto fáze. Vo fáze využitia, musia byt' nové produkty, služby alebo licencie rýchlo „pretavené“ do zisku.

Znalostný manažment tvorí základ pre účinný a efektívny inovačný manažment. V súlade so základným modelom znalostného manažmentu popísanom na obrázku 2 sa jedná sa o interakciu medzi tromi rôznymi úrovňami. 


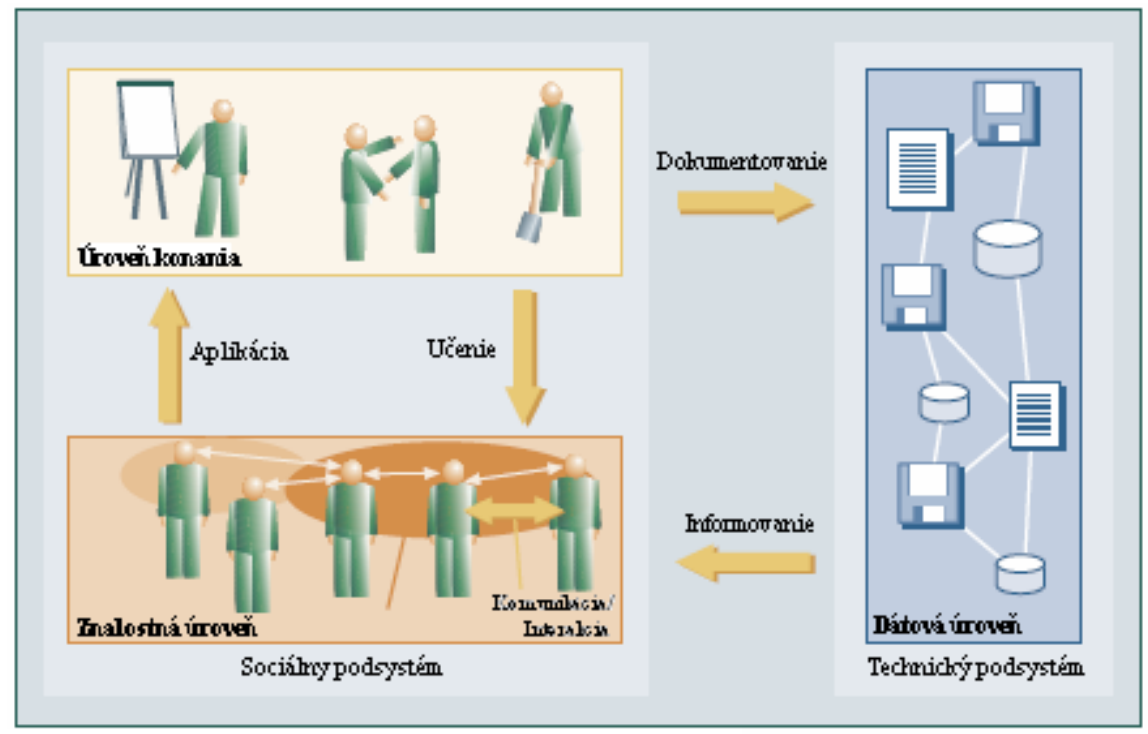

Obrázok 2: Základný model znalostného manažmentu [2]

Úroveň projektu musí byt' jasne štruktúrovaná do štyroch fáz inovácií, ako je popísané vyššie. Experti (s odbornými a metodickými znalost’ami a sociálnymi zručnost’ami) sa nachádzajú na znalostnej úrovni a komunikujú priamo s projektovou úrovňou. Všetky údaje a dokumenty dôležité pre inovácie sú sústredené na úrovni dát. Tie sú k dispozícií v celom inovačnom procese využitím moderných informačných a komunikačných nástrojov. Hladká integrácia medzi znalostnou a dátovou úrovňou je kl'účovým faktorom pre úspech inovačných projektov.

\section{Optimalizácia procesu riešenia problému}

Napriek existencii vel'kého počtu elektronických podporných nástrojov, bolo urobených pomerne málo zmien v procesoch, ktoré mali riešit' určitý problém. Procesne orientovaný prístup k riešeniu problémov môže výrazne zvýšit' účinnost' a efektívnost'. Zameranie na znalostnú perspektívu, v organizácii takýchto procesov, zdôrazňuje potenciálnu súčinnost' medzi procesmi a znalostným manažmentom. Procesy riešenia problému musia byt' navrhnuté tak, aby vyhovovali aktuálnym obchodným podmienkam a mali by využívat' existujúce znalosti spoločnosti. Napríklad vtiahnutie zamestnancov do návrhu procesu riešenia problému, môže znamenat' faktor úspechu a viest' k radikálnemu zlepšeniu spôsobu, akým sú problémy riešené. Nasledujúci zoznam obsahuje niektoré bežné príklady nedostatkov V súčasných procesoch riešenia problému:

o Nie je definovaný žiadny proces riešenia problému.

o Boli zaznamenané zlé skúsenosti s existujúcimi procesmi riešenia problému.

o Nie sú využívané empirické znalosti na zlepšenie procesu (napr. databázy alebo expertné skupiny).

o Riešenie problému nie je súčast'ou dennej rutiny. Na riešenie problému nie sú vyčlenené žiadne d’alšie zdroje (čas/pracovníci) a neexistuje žiadny motivačný systém.

o Nie sú vykonávané žiadne systematické analýzy príčin vzniku problému, a väčší dôraz sa kladie na liečbu príznakov. Problémy sú vyhodnotené subjektívne „inštinktom“.

o Problémy s databázou s komplikovaným užívatel'ským rozhraním a byrokratické obmedzenia prístupu blokujú informačné a dokumentačné procesy. 
o Nie sú stanovené znalostné požiadavky pre jednotlivé fázy procesu riešenia problémov. Zamestnanci sú pridel'ovaní na riešenie problému podl'a dostupnosti (a nie pre svoje odborné skúsenosti a znalosti).

o Neberie sa žiaden ohl'ad na možnost' integrácie externých majitel’ov znalostí do procesu riešenia problémov.

o Rozvoj riešenia nie je považovaný za súčast' procesu riešenia problému.

o Vývoj riešení nie je plánovaný vopred, čo spôsobuje oneskorenie celého procesu.

Ak organizácia preukáže, viac ako dva vyššie uvedené nedostatky, odporúča sa preskúmat' a zlepšit' jej procesy riešenia problémov.

\section{Problémy hodnotenia}

Jednou z kl'účových otázok pri riešení problému, je stanovenie potenciálnej hrozby, ktorú by pre spoločnost' mohlo znamenat' nevyriešenie problémov. Tento faktor môže byt' použitý pre zvýšenie priority problému a pridelenie dostatočných zdrojov na jeho vyriešenie. Možná hrozba je bezrozmerný ukazovatel' toho, do akej miery skutočne problém ohrozuje prežitie organizácie. Schopnost' organizácie prežit', závisí predovšetkým od jej schopnosti splnit' požiadavky zainteresovaných strán. Z hl'adiska znalostného manažmentu si to vyžaduje získanie príslušných znalostí pre zúčastnené strany a ich požiadavky, pričom tieto znalosti môžu potom slúžit' na určenie možných vplyvov, ktoré môže mat' problém na schopnost' organizácie splnit' tieto požiadavky a v konečnom dôsledku je stým spojené aj prežitie organizácie. [2]

Od príznaku k problému: termín „problém“ je všeobecne používaný na označenie určitej odchýlky medzi ciel'ovou a aktuálnou situáciou alebo odchýlky medzi požadovaným stavom a realitou. Systematický prístup k riešeniu problémov sa zameriava na odlíšenie príznaku (tj. problém v širšom slova zmysle) od koreňov problému (tzn. problém v užšom slova zmysle). Nasledujúci príklad jasne ilustruje význam tohto rozlíšenia: výrobca prevodoviek si uvedomil, že gul'ôčkové ložisko sa pokazilo po niekol'kých hodinách prevádzky, čo spôsobuje obrovské problémy zákazníkom. Naliehavost' situácie viedla výrobcu k tomu, aby prijal okamžité opatrenia úpravou nastavení tolerancie ložiska. Hoci to bolo mierne zlepšenie, v skutočnosti to neriešilo problém, a výrobca prevodoviek musel čelit' obrovským nákladom $\mathrm{v}$ dôsledku pokračujúcich porúch . Neboli podniknuté kroky s ciel'om určit príčinu problému a prijaté opatrenia riešili skutočne iba príznaky, nie problém sám o sebe. V tomto prípade by komplexné hodnotenie možných hrozieb, odkrylo naliehavú potrebu podrobnej analýzy problému.

Okrem osvedčených metód (napr. Ishikawov diagram) je analyzovanie faktorov výborný spôsob určenia príčiny problému, pretože izoluje "hlavnú" príčinu (tj problém v užšom slova zmysle), z väčšieho počtu možných príčin.

\section{Záver}

Jasné vymedzenie jednotlivých fáz inovácií a optimálne prepojenie znalostnej, dátovej a projektovej úrovne tvorí, základ pre úspešné inovačné procesy.

Ked’že počet a zložitost' problémov aj nad'alej rastú, optimalizácia procesov a riešenie problémov, sa stávajú čoraz dôležitejšie. Stupeň naliehavosti možno stanovit' hodnotením niekol'kých kl'účových faktorov. 
Uprednostnenie problému podl'a potenciálu hrozby je osobitne účinný spôsob zaistenia primeraných zdrojov pre činnosti celopodnikového riešenia problémov. Identifikácia príčin problému musí zohrávat' ústrednú úlohu v každom procese riešenia problému.

\section{Literatúra}

[1] ŠTOFKOVÁ, J. a kol., Manažment podniku, vydavatel’stvo EDIS, 2008, ISBN 978-8070 $-713-2$

[2] WISSENSMANAGEMENT FORUM: An illustrated guide to Knowledge management, Graz, Austria, 2003

[3] ŠUJANOVÁ, J.; VÝBOCH, J.; REŠETOVÁ, K.: Informačný manažment. Bratislava: STU v Bratislave, 2007. 216 s. ISBN 978-80-227-2602-3.

[4] HORŇÁK F.: Inovačný manažment, prednášky, STU, Bratislava

[5] TUREKOVÁ, H.; MIČIETA, B.:Inovačný manažment, EDIS 2003, ISBN 80-8070-055-9

[6] http://www.systems-thinking.org/kmgmt/kmgmt.htm

\section{Grantová podpora}

Príspevok je publikovaný v rámci riešenia projektu VEGA 1/0757/09 Metódy a techniky strategického manažmentu ako nástroje zvyšovania efektívnosti podniku, projektu VEGA 1/0760/10 Využitie strategického manažmentu pre podporu rozvoja regiónov, projektu VEGA 1/0709/08 Poskytovanie verejnej telefónnej služby a spôsoby jej hodnotenia v procese globalizácie, Inštitucionálneho výskumu 5/KS/09 Strategický manažment ako podporný faktor rozvoja podniku a projektu VEGA 1/0468/08 Inovačné stratégie v sektore služieb. 